\title{
बुद्धधर्ममा कर्म र कर्मफल
}

\section{ललिता धाख्वा,"}

\section{सार}

चेतना युक्त भई मानिसले शरीर, वचन र मनले गर्ने सम्पूर्ण क्रियाकलापहरू कर्म हुन् । कर्म र कर्मफल बीच कारण र परिणामको सम्बन्ध रहेको हुन्छ। कर्मको नियमअनुसार कुशल (राम्रो) कर्मले कुशल फल दिन्छ र अकुशल (नराम्रो) कर्मले अकुशल फल दिन्छ। बुद्धर्ममा कर्म र कर्मफलको वारेमा सही दृष्टिलाई (यथार्थता) आत्मसात् गर्नुपर्ने कुरामा जोड दिइएको छ। कर्म र कर्मफलमा विश्वास तथा स्वीकार गर्नु एक प्रकारको सम्यकदृष्टि (सही धारणा) हो भनिएको छ। मानिसले गर्ने कर्मको आधारमा नै उसले सुख र दु:ख जीवनमा भोग गर्ने हुन्छ। त्यसैले मानिसहरूको कर्म नै आ-आफ्नो निजी सम्पत्ति हुन् भनिएको छ। बुद्धले आफ्नो मालिक आफें हो आफू बाहेक अरु कोही आफ्नो मालिक हुन सक्दैन भनेर व्यक्तिको आफ्नो प्रयासलाई सर्वोपरि महत्त्व दिई धर्ममा स्वावलम्बी हुने शिक्षा दिनुभएको छ। प्रस्तुत लेखमा कर्म र चेतनाको सम्बन्ध, कुशल कर्म, अकुशल कर्म, दशपुण्यक्रिया, कर्म र कर्मफल बीच अन्तरसम्बन्ध, कर्मका प्रकार, व्यक्ति स्वयं कर्मको भागिदार जस्ता विषयवस्तु प्रस्तुत गरिएको छ। यी विषयहरू मनन गर्न सकेमा कर्म र कर्मफल सम्बन्धी सम्यकदृष्टि विकास गर्न मद्धत मिल्नेछ। गलत कर्म र सही कर्म पहिचान गर्न सक्ने भई अकुशल कार्यहरूलाई त्यागी कुशल कार्यहरू गर्ने तथा आफूभित्र असल गुणहरूको विकास गरी मनुष्य जीवनलाई सार्थक बनाउन सकिन्छ।

शब्द कुज्जिका : कर्म, कर्मफल, कुशल, अकुशल, पुण्यक्रिया, सुगति, दुर्गति, सम्यकदृष्टि, मिथ्यादृष्टि ।

\section{समस्या कथन}

कर्मको नियमअनुसार कुशल कर्मले कुशल फल दिन्छ र अकुशल कर्मले अकुशल फल दिन्छ। कर्म र कर्मफल बीच कारण र परिणामको सम्बन्ध रहेको हुन्छ । कर्म कारण र फल परिणाम हो । कुशल कर्मले परिणामको रूपमा सुखद प्रतिफल दिन्छ भने अकुशल कर्मले दु:खद प्रतिफल दिन्छ। कर्म सम्बन्धी यी तथ्यलाई आत्मसात गर्न नसक्दा मानिसले अकुशल कर्म गर्न पुग्छन्। जीवनमा सुख चाहँदा चाहँदै पनि दु:खमा फसेको देखिन्छ। समाजमा कतिपय मानिसहरू कुशल र अकुशल कर्म के हो भन्ने विषयमा अन्यौल देखिन्छ। तसर्थ यी तलका विषयवस्तुमा केन्द्रित भई लेख तयार पारिएको छ :

१. बुद्धधर्म अनुसार कर्म के हो ? चेतना युक्त कुशल कर्म र अकुशल कर्म के कस्ता छन् ?

२. कर्म र कर्मफल बीच कस्तो अन्तरसम्बन्ध छ, ?

३. कुशल तथा अकुशल कर्मको भागिदार मानिस आफै कसरी हुन्छ ?

* उपप्राध्यापक, पाटन संयुक्त क्याम्पस, त्रि.वि., पाटनढोका । 


\section{उद्देश्य}

बुद्धधर्मअनुसार कुशल र अकुशल कर्मबारे प्रकाश पार्ने, कर्म र कर्मफलबीचको अन्तरसम्बन्ध सम्बन्धी बुद्धका उपदेशहरूलाई उजागर गर्ने तथा कर्म निर्माण र भोग गर्नमा व्यक्ति स्वयं जिम्मेवार हुन्छ भन्ने तथ्यलाई प्रकाश पार्ने उद्देश्यले यो लेख तयार पारिएको छ।

\section{अनुसन्धान विधि}

प्रस्तुत लेख विवरणात्मक र विश्लेष्णात्मक अनुसन्धान विधि अपनाइएको छ। प्राथमिक र द्वितीय स्रोतमा अन्तरनिहित भएर तयार गरिएको छ। प्राथमिक स्रोतको रुपमा पालि भाषाका तिपिटक ग्रन्थहरू तथा पालि भाषाबाट नेपालीमा अनुवादित तिपिटक ग्रन्थहरूलाई लिइएको छ। त्यस्तै विज्ञहरूबाट लेखिएका कर्म र कर्मफलसँग सम्बन्वित पुस्तकहरूलाई द्वितीय स्रोतको रूपमा लिइएको छ।

\section{विषय प्रवेश}

पालि व्याकरणमा 'करीयतीति कम्मं' 9 अर्थात् 'गर्नुपर्ने हुनाले कर्म भनिन्छ' भनी अर्थ दिइएको छ। जसअनुसार कर्मको अर्थ काम हो। मानिसले शरीर, वचन र मनले गर्ने सबै क्रियाकलापहरू कर्म नै हुन्। तर बुद्ध धर्ममा कर्म र काम बीचको भिन्नतालाई देखाइएको छ। मानिसले गर्ने सबै काम कर्म होइनन्, तर सबै कर्म काम नै हुन्। चेतनायुक्त भई गरिएका कामलाई मात्र कर्म भनिएको पाइन्छ। यस सम्बन्धमा बुद्धवचनलाई अंगुत्तर निकायको निब्बेधिकसुत्तमा ${ }^{2}$ यसरी उल्लेख गरिएको छ:

चेतनाहं भिक्खवे, कम्म वदामि। चेतयित्वा कम्म करोति- कायेन वाचाय मनसा ।

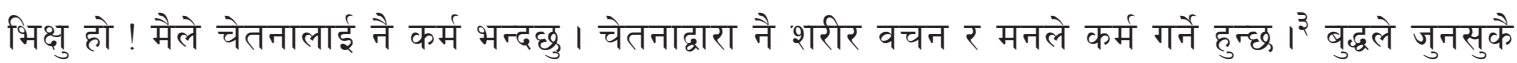
कर्म बन्नका लागि तीन प्रकारका चेतना आवश्यक हुने कुरामा जोड दिनुहुन्छ। ती चेतनाहरू निम्न छन् -

१. पुब्बचेतना - कर्म गर्नुअघि विचार गर्नु वा ईच्छा गर्नुलाई 'पुब्बचेतना' भनिन्छ।

२. मुन्चचेतना - कर्म गरिरहेको समयमा विचार गर्नुलाई 'मुज्चचेतना' भनिन्छ।

३. अपरचेतना - कर्म गरिसकेपछि, गरिसकेको कर्मबारे सम्भिनु वा विचार गर्नुलाई 'अपरचेतना' भनिन्छ। ${ }^{\gamma}$

यी तीन चेतनायुक्त भई कुशल (राम्रो) वा अकुशल (नराम्रो) काम गरेको खण्डमा त्यसै अनुसारको कर्मफल भोग गर्नुपर्ने हुन्छ।

$१$ अनागारिका अग्गजाणी, पालि शिक्षा र संक्षिप्त व्याकरण, काठमाण्डौ : दिलरत्न शाक्य, विद्या शाक्य, वि.सं. २०६७, पृ. १४१ ।

२ विपश्यना विशोधन विन्यास, अडुत्तर निकायो (दुतियो भागो), इगतपुरी : विपश्यना विशोधन विन्यास, १९९५, पृ. ११६।

३ भिक्षु बोधिसेन महास्थविर (अनु.), अडुत्तर निकाय (छक्क निपात), ललितपुर : अनागारिका वीर्यपारमिता, वि. सं. २०६७., पृ.१२३।

४ भद्दन्त सम्यकसम्बोधि प्राणपुत्र, सम्यक शिक्षा, बेनी : म्यागदी बौद्ध संघ, वि.सं. २०६३, पृ. ३०। 
बुद्धधर्मअनुसार सुख र दु:ख सबै कर्मकै फल हुन् भनी व्याख्या गरिएको छ। कुशल र अकुशल कर्मको परिणामबारे भगवान् बुद्ध भन्नुहुन्छ -'मनसा चे पसन्नेन, भासति वा, करोति वा, ततो नं सुखमन्वेति, छाया व अनपायिनी'火 अर्थात् शुद्ध मनले कुरा वा काम गर्ने व्यक्तिमा आफ्नो पिछा नछोड्ने छायाँ भैं सुख पछि, पछि, आउँछ। त्यस्तै 'मनसा चे पदुट्टेन, भासति वा करोति वा, ततो नं दुक्खमन्वेति, चक्कंव वहतो पद, ६ अर्थात् अशुद्ध मनले कुरा वा काम गर्ने व्यक्तिको जीवनमा गाडा तान्ने बयलको पछि पछि गाडाको पांग्रा आए कै दु:ख पछि पछि आउँछ। तसर्थ नियतवस कुशल कर्म गरेमा फल पनि कुशल नै र अकुशल कर्म गरेमा अकुशल फल नै पाउने प्रष्ट हुन्छ।

चेतनायुक्त कर्म कुशल र अकुशल गरी दुइ प्रकारका छन्। राम्रो बानी व्यवहार, असल चरित्र र पुण्यकार्यलाई कुशल कर्म र नराम्रो बानी व्यवहार, खराब चरित्र र पापकार्यलाई 'अकुशल कर्म' भनिन्छ। ${ }^{9}$

कुशल वा अकुशल कर्म जुन शरीरद्वारा गरिएमा कायिक, वचनद्वारा गरिएमा वाचसिक र मनद्वारा कल्पना चिन्तना गरिएमा मानसिक कर्म भनी तीन प्रकारले विभाजन गरिएको छ। शरीर, वचन र मनलाई द्वारको रूपमा लिइएको छ, जसको माध्यमबाट दश प्रकारका कुशल कर्महरू तथा दश प्रकारका अकुशल कर्महरू भइरहन्छन् ।

\section{दश अकुशल कर्म}

दश अकुशल कर्महरूमध्ये कायिक कर्म तीनवटा, वाचसिक कर्म चारवटा र मानसिक कर्म तीनवटा निम्नानुसार छन् -

\section{कायिक कर्म तीनवटा}

१) पाणातिपात -चेतनशील सत्वहरूलाई हत्या गर्नु, मार्नु ।

२) अदिन्नादान - अर्काको अधिकारमा रहेको कुनै पनि चीजवस्तु नदिईकन जबरजस्ती लिनु वा चोरी गर्नु ।

३) कामेसु मिच्छाचारा - परपुरुष वा परस्त्री गमन गर्नु अर्थात् आमाबाबु, दाजुभाइ, दिदीबहिनी, कुटुम्ब परिवार गोत्रबाट रक्षा गरिएको, कसैसँग विवाह भइसकेको, कसैको लोग्ने वा स्वास्नी भएको, नारी पुरुषदेखि लिएर दास-दासीसम्मलाई कामभोगका लागि अतिक्रमण गर्नु ।

\section{वाचसिक कर्म चारवटा}

४) मुसावाद - भूटो बोल्नु, असत्यलाई सत्य भन्नु, सत्यलाई असत्य भन्नु, भूटो कुरामा साक्षी बस्नु इत्यादि ।

४) पिसुणवाचा - चुक्ली गर्नु, आपसमा सत्कार सम्मान एवं विश्वासी भइरहेकाहरूलाई उनीहरूको सम्मानमा धक्का पर्ने गरी बोल्नु र मिलिरहेका दुइजनाको चित्त फाट्ने कुरा गर्नु ।

\footnotetext{
$y$ भिक्षु अमृतानन्द (अनु.), धम्मपद, गाथा नं २, काठमाण्डौ : आनन्दकुटी विहार संस्था, वि.सं, २०७०, पृ. २।

६ उही, गाथा नं १, पृ. १।

७ भिक्षु ज्ञानपूर्णिक (अनु.), कर्म र मनुष्य, ललितपुर : सन्ति सुखावास, वि.सं. २०४४ ४, पृ. ३।
} 
६) फरुसवाचा - अरुको इज्जतमा धक्का पर्ने गरी गाली गर्नु, रिसले कटुवचन बोल्नु, अपशब्द बोल्नु, जथाभावी बोल्नु वा कडा वचन प्रयोग गर्नु ।

७) सम्फप्पलापवाचा - बेकारको कुरा गर्नु, अनर्थको कुरा गर्नु, धर्मविनय विपरीत कुरा गर्नु, बेतर्कको कुरा गर्नु ।

\section{मानसिक कर्म तीनवटा}

द) अभिज्का - लोभी हुनु, अर्काको धनसम्पत्ति आफ्नो बनाउन पाए हुन्थ्यो भन्ने भावना नै अभिज्का हो । अभिज्कालाई विषमलोभ, राग तथा काम पनि भनिन्छ।

९) व्यापाद - अरुलाई दु:ख दिने मनसाय, द्वेषयुक्त संकल्प, आघात, दुष्ट मनस्थिति नै व्यापाद हो । यसलाई कोध, द्वेष, प्रतिघ, रोष पनि भनिन्छ।

१०) मिच्छादिद्टि - विपरीत दृष्टि, गलत र उल्टो धारणालाई ‘मिच्छादिद्धि' भनिन्छ। दान गर्नुको फल छैन, राम्रो नराम्रो कामको फल छैन। इहलोक छैन, परलोक छैन। आमा, बाबु भन्ने पनि छैनन्। यो संसारमा सम्यक् ज्ञान प्राप्त व्यक्ति पनि छैन। सही आचरण भएका पनि छैंनन् भन्ने धारणालाई नै 'मिच्छादिद्ठि' भनिन्छ। इ $^{5}$

यी दशवटा अकुशल कर्म नराम्रा आचरणले मानिसलाई उन्नतिको सत्ता पतनतिर ढकेल्छ,। यस्ता कर्म गर्ने चरित्रहीन मानिसले यस वर्तमान जीवनमा पनि दु:ख पाउने तथा मरणपछि पनि दुर्गतिमा पतन भई दु:ख भोग गर्नु पर्ने हुन्छ। तसर्थ यी दश अकुशल कर्म असाधु (नराम्रो), सदोष (दोषसहित), दु:खदायक, अनार्य मार्ग, कृष्णमार्ग (अँध्यारो बाटो) हुन् ।। दश अकुशल कर्मलाई पाप पनि भनिन्छ । $^{\rho}$

\section{दश कुशल कर्म}

शरीरबाट हुने राम्रो क्रियाकलाप, वचनबाट बोलिने राम्रो बोली वचन, मनबाट गरिने राम्रो चिन्तन मनन र सही धाराणादि कुशल कर्म हुन् । दुश्चरित्र कर्मबाट अलगग हुनु नै कुशल कर्म हो। कुशल कर्म दश प्रकारका छन् :

\section{कायिक कर्म तीनवटा}

१. पाणातिपाता विरति - प्राणिहिंसाबाट अलगग भई दण्डको प्रयोग, शस्त्रको प्रयोग नगरिकन दयावान भई सबै प्राणीप्रति अनुकम्पा राख्नु ।

२. अदिन्नादाता विरति - चोरी काम छोडेर आफ्नो मेहनतले जति प्राप्त हुन्छ, त्यसैलाई मात्र ग्रहण गरी पवित्र जीवन व्यतित गर्न ।

३. कामेसु मिच्छाचारा विरति - कामभोग सम्बन्धी मिथ्याचारलाई छोड्नु अर्थात् परस्त्री वा परपुरुष गमन गर्नुबाट अलगग रहनु ।

वाचसिक कर्म चारवटा

४. मुसावादा विरति - फटाहा कुरा गर्नुबाट अलग भई सत्य कुरा गर्नु, यथार्थवादी हुनु ।

ᄃ अमिता धाख्वा र अरुहरू (सं), परियत्ति शिक्ष तह-२, काठमाण्डौं : अखिल नेपाल भिक्षु महासंघ, वि.सं २०७७, पृ. ५ू-७।

$९$ अनागारिका अगगजाणी (अनु.), पपतित सूत्रया व्याख्या, काठमाण्डौं : अन्तराष्ट्रिय बौद्ध भावना केन्द्र, वि.सं २०६७, पृ. १०-११। 
५. पिसुणवाचा विरति - चुगली गर्ने काम छोडी, भगडा हुने कामबाट अलग भई वैमनष्य भाव हटाइदिने, परस्परमा मेलमिलाप हुने कुरा गर्नु ।

६. फरुसवाचा विरति - कडा वचन बोल्न छोड्नु। सुन्नमा आनन्द हुने, मन प्रसन्न हुने सभ्य वचन प्रयोग गर्नु।

७. सम्फप्पलापवाचा विरति - फजुल व्यर्थ कुरा छोडी समयानुकूल यथार्थ, अर्थयुक्त, तर्कयुक्त कुरा गर्नु ।

\section{मानसिक कर्म तीनवटा}

५. अनभिज्का - निर्लोभी भई अर्काको धनमाथि लोभ नगर्ने हुनु ।

९. अव्यापाद - द्वेषरहित भई कुनै पनि प्राणीप्रति शत्रुभाव नराखी सुखी होस् भनी मैत्री चित्त राखनु ।

१०. सम्मादिठ्ठि - गलत धारणा नराखिकन सही धारणा राख्नु अर्थात् कुशल कर्मको फल राम्रो हुन्छ, अकुशल कर्मको फल नराम्रो हुन्छ भनी कर्म र कर्मफलमा विश्वास गर्ने सही धारणा राख्तु नै सम्मादिहि हो । ${ }^{\circ}$ यी दश कुशल कर्म साधु (राम्रो), निर्दोष, सुखदायक, आर्य मार्ग, शुक्लमार्ग (उज्यालो बाटो) हुन् । यस्ता कर्म गर्ने मानिस सही आचरणका कारण सुगति स्वर्गमा उत्पन्न हुन्छ। तसर्थ दश कुशल कर्मलाई धर्म पनि भनिन्छ, ११ $^{99}$

दश कुशल कम उन्नतिको बाटो हो। तसर्थ अकुशल वा कुशलको भेद थाहा पाई कुन बाटो रोज्ने भन्ने कुरा व्यक्तिमै भर पर्दछ।

\section{दशपुण्यक्रिया}

पुण्य प्राप्त हुने अथवा भाग्य बन्ने दशवटा क्रियाहरू छन् । यसलाई दश 'पुण्यक्रिया'१२ भनिन्छ। यिनीहरू पनि दश-कुशल धर्म नै हुन् जुन निम्न प्रकारका छन् -

9) दान - आफूसँग भएको चीजवस्तु अरुको हितको निम्ति दिनु वा त्याग गर्नु ।

२) शील - शरीर र वचनलाई संयमित गर्ने अभ्यास वा सदाचार ।

३) भावना - चित्तलाई शुद्ध र निर्मल हुने गरी अभ्यास गर्नु ।

४) अपचायन - आफूभन्दा जेष्ठहरूको आदर गर्नु ।

५) वेय्यावच्च - सेवा गर्नु, आफन्तहरूलाई मद्दत गर्नु।

६) पत्तिदान - आफूले गरेको कुशल कर्मको भाग वा पुण्य अरुलाई बाँड्नु।

७) पत्तानुमोदन - अरुले गरेको पुण्य वा राम्रो काममा प्रसन्न भई साधु अनुमोदन गर्नु ।

५) धम्मसवन - धर्म उपदेश सुन्नु ।

९) धम्मदेसना - धर्म उपदेश दिनु वा बताउनु ।

१०) दिट्टिजुकम्म - ठीक धारणा वा यथार्थ दृष्टि राखी कर्म र कर्मफलमा विश्वास गर्नु ।

90 धाख्वा र अरुहरू, पादटिप्पणी नं.ढ, पृ. ५-९।

११ अनागारिका अग्गजाणी, पादटिप्पणी नं.९, पृ. १०-११।

१२ धाख्वा र अरुहरू, पादटिप्पणी नं. द, पृ. १०। 
यी माथि उल्लेखित पुण्य कर्महरू सम्पादन गर्नु, अकुशल कर्म परित्याग गर्दे चित्त शुद्धताको अवस्थासम्म पुग्नु नै बुद्धशिक्षाको सार हो, जुन कुरा धम्मपदमा ज्ञ यसरी उल्लेख गरिएको पाइन्छ -

सब्बपापस्स अकरणं - कुसलस्स उपसमपदा ।

सचित्तपरियोदपनं एतं बुद्धानसासनं ॥

कुनै पाप कर्म नगर्नु, कुशल कर्म गर्नु र आफ्नो चित्तलाई परिशुद्ध गर्नु यही नै बुद्धहरूको शिक्षा हो ।

\section{कर्म र कर्मफल बीच अन्तरसम्बन्ध}

कर्मको नियमअनुसार कुशल कर्मले राम्रो फल दिन्छ, अकुशल कर्मले नराम्रो फल दिन्छ अर्थात् जसले जस्तो कर्म गछ उसले त्यस्तै फल भोग्छ। यस सन्दर्भमा संयुत्तनिकायमा जद्ध यसरी उल्लेख गरिएको छ-

यादिसं वपते बीज, तादिसं हरते फल ।

कलयाणकारी कल्याणं, पापकारी च पापकं।

जस्तो बीउ रोप्यो त्यस्तै फल पाउँछ। कल्याणकारीले कल्याण, पापकरीले पाप भोग गर्दछ।

यसरी कर्म र कर्मफल बीच कारण र परिणामको सम्बन्ध रहेको छ। कर्मको प्रतिफल बारेमा निब्बेधिक सुत्तमा $^{94}$ यसै जन्ममा, अर्को जन्ममा वा कुनै जन्ममा कर्मभोग गर्नु नै कर्मको प्रतिफल हो भनी उल्लेख गरिएको छ। यस जन्ममा दान दिएर, शील पालन गरेर, ज्ञानबुद्धि लगाई प्रयत्न गरी इमान्दारपूर्वक जीवन निर्वाह गरिरहेता पनि कहिलेकाहीं जीवनमा उन्नति अभिबृद्धि नभई दु:ख सामना गर्नुपर्ने हुन्छ । यसरी हुनु भनेको राम्रो कर्म गरेर नराम्रो प्रतिफल पाएको होईन । वर्तमान राम्रो कर्मले प्रतिफल दिईनसकेको र त्यतिन्जेल अतीत जन्मको कर्मले गर्दा फल भोग्ने अवसर मिलेको हो । कर्मको नियम नजानेकाहरूले राम्रो गर्नेहरूलाई कन् दु:ख हुन्छ, धर्म गरेर पनि पाप भोग्नु परेको इत्यादि भन्ने गर्दछ,। त्यस्तै वर्तमान जन्ममा मानिसहरू दुराचारी भई अनैतिक कृयाकलाप गरी जीविका गरेता पनि उनीहरूको जीवनमा उन्नति प्रगति भइरहेको हुन्छ । यस्तो हुनु नराम्रो कर्मले राम्रो प्रतिफल दिएको होइन । वर्तमान नराम्रो कर्मले प्रतिफल दिइनसकेको र त्यतिन्जेल अतीत जन्मको राम्रो कर्मले गर्दा राम्रो फल भोग्ने अवसर मिलेको हो। कर्मको नियम नजानेकाहरूले नराम्रो गर्नेहरूलाई कन् सुख हुन्छ, पापीहरूको जय हुन्छ इत्यादि भन्ने गर्दछ, ।द यसरी कुशल कर्म गरेको होस् वा अकुशल कर्म त्यसको फल अवश्य भोग गर्नु पर्दछ। निब्बेधिक सुत्तमा $^{9 \vartheta}$ कर्मको नानात्व बारेमा यसरी उल्लेख गरिएको छ-कर्मले नरक भोग गराउने हुन्छ, कर्मले पंक्षिको

१३ भिक्षु अमृतानन्द (अनु.) गाथा नं.१६३, पादटिप्पणी नं, ४ र, पृ. ५ ४।

१४ दुण्डबहादुर बज्राचार्य (अनु.), संयुक्तनिकाय, ललितपुरः वीर-पूर्ण पुस्तक संग्रहालय, वि.सं. २०४५, पृ. २प७।

१४ भिक्षु बोधिसेन महास्थविर (अनु.), पादटिप्पणी नं ३, प्. १२३।

१६ अनागारिका अग्गजाणी, सद्धर्म पुष्पमाला, ललितपुरः अष्ट रत्न धाख्वा, रत्नदेवी धाख्वा परिवार, वि.सं २०७०, पृ. १६।

१७ भिक्षु बोधिसेन महास्थविर (अनु.), पादटिप्पणी नं ३, पृ.१२३ 
योनिमा भोग गराउने हुन्छ, कर्मले प्रेत योनिमा भोग गराउने हुन्छ, कर्मले मनुष्यको जन्ममा भोग गराउने हुन्छ अनि कर्मले देवलोकमा भोग गराउने हुन्छ। यसैलाई कर्मको 'नानात्व' भानिन्छ।

\section{कर्मका प्रकार}

पालि साहित्यमा विभिन्न आधारमा बिभिन्न प्रकारका कर्महरू देखाइएको पाइन्छ। सबै कर्मले एक नाशले फल दिंदैन। कर्मको क्षमताअनुसार फल दिने फरक हुन्छ। फल दिने क्षमताअनुसार कर्म चार प्रकारका छन् :

गरूक, आसन्न, आचिण्णं, कटत्ताकम्मः्चेति पाकदानपरियायेन ।१

क) गरूककम्म - शक्तिशाली फल दिने भारी कर्मलाई 'गरूककम्म' भनिन्छ। कुशल पक्षमा लौकिक ध्यान प्राप्त व्यक्तिको कर्म तथा अकुशल पक्षमा पज्चमहापाप (बुवाको हत्या, आमाको हत्या, अरहन्तको हत्या, बुद्धलाई चोट पुर्याउनु, संघभेद) कर्म नै गरूककम्म हो। कुशल वा अकुशल गरूककम्म गरिएको छ भने फल आउँदा सबैभन्दा पहिले यसै कर्मको फल भोग गर्ने हुन्छ। फलको रूपमा या त ब्रम्हलोक या नरकभोग गर्ने हुन्छ। लौकिक ध्यान प्राप्त व्यक्ति मरणपछि, ब्रम्हलोकमा उत्पन्न हुन्छ भने पन्चमहापापमध्ये कुनै एक मात्र कर्म गरेता पनि नरकमा पतन हुन्छ। उदाहरणको रूपमा देवदत्तको कर्मलाई लिन सकिन्छ। देवदत्तले भगवान् बुद्धप्रति द्वेषभाव भएको कारण बुद्धलाई मार्नको लागि गृद्धकुट पर्वतबाट ढुड़ा प्रहार गरेका थिए, जसको कारण बुद्धको खुट्टाको औँलामा चोट पुग्यो र रगत निस्केको थियो। त्यसैगरी देवदत्तले संघभेद पनि गरेको थियो। यी महापाप गरेका कारण त्यस जन्मबाट अर्को जन्म अभिंचि नरकमा लिन पुगे ।

ख) आसन्नकम्म - मरणासन्न कालमा गरिने कुशल वा अकुशल कर्मलाई 'आसन्नकम्म' भानिन्छ। मरण हुनु भन्दा ठीक अघि दान, शील आदि कुशल कर्म गर्दे शान्त मनले खुशीसाथ मरण भएमा अर्को जन्ममा सुगति प्राप्त हुन्छ। त्यसैले मरण हुन लागेका मानिसलाई आफन्तहरूले दानादिकर्म गराउने, भजन, पूजा पाठ गराउने आदि कुशलकर्म गरिन्छ। यो अवस्थामा जुन कर्म गर्दछ, सो अनुसार अर्को जन्मको लागि गति निर्धारण हुन्छ। यद्यपि मरणावस्थामा मात्र असल गरे पुग्छ भने सोच राख्नु गलत हो । मरण अवस्था पीडादायी अवस्था हो । पुण्य कार्य निरन्तर अभ्यास गरेको छ भने मात्र त्यस्तो अवस्थामा कुशल कार्यलाई निरन्तरता दिन सक्ने हुन्छ। तर जिन्दगीभर कुनै पुण्य नगरीकन मरणासन्न अवस्थामा मात्र कुशल कर्म गर्नु सम्भव हुँदैन । कुनै एउटा नराम्रो कर्म याद आई त्यहीं निमित्त ग्रहण गरी मरण भएमा दुर्गतिमा जन्म लिन पुग्छ। उदाहरणस्वरुप कोशल राज्यकी रानी मलिकाको कर्मलाई लिन सकिन्छ। बुद्धप्रति श्रद्धा राखी दान दिने उपदेश सुन्ने आदि कुशल कर्म गरेता पनि मरण अवस्थामा आफूले गरेको अनैतिक कार्यलाई स्मरण गर्दा सात दिनसम्म नरक भोग गर्नुपरेको थियो। तर पछि पूर्वजन्ममा गरेका कुशल कर्महरूको प्रभावले देवलोकमा उत्पन्न भयो।

१६ विपश्यना विशोधन विन्यास, अभिधम्मत्थस्जहो अभिधम्मत्थविभाविनीटीका.इगतपुरी: विपश्यना विशोधन विन्यास, १९९५, पृ. ३६। 
ग) आचिण्णकम्म - जीवनकालमा अत्याधिकरूपमा अभ्यस्त हुने गरी गरिएको कर्मलाई 'आचिण्णकम्म' भनिन्छ। जस्तै:

सिकारीको हिंसा कर्म, ध्यानीको ध्यान कर्म । जीवनमा बारम्बार दोहोयाउदै गर्ने कर्म नै आचिण्ण कर्म हो । कसैले जीवनमा कुनै गरुक अर्थात् भारी कर्म गरेको छैन, आसन्न कर्म पनि गरेको छैन भने आचिन्न कर्मले अर्को जन्म निर्धारण गर्दछ। जस्तै नित्य रूपमा दान दिने, शील पालन गर्ने बानी भएका व्यक्ति मरण अवस्थामा पुगदा यी कर्महरू प्रकट हुन्छ। जुन कर्म निमित्तले सुगतिमा अर्को जन्म दिन्छ। त्यस्तै कुनै व्यक्तिले जीवनभर हिंसा, चोरी इत्यादि अकुशल कर्म गरी जीविका चलाएको छ भने मरणासन्न अवस्थामा यी कर्महरू प्रकट हुन्छ र दुर्गतिमा नयाँ जन्म दिन्छ। बुद्धकालीन समयमा विहार दान गर्ने त्यस्तै नित्य रूपमा बुद्ध तथा धर्ममा समर्पित दाताहरू अनाथपिण्डिक महाजन, विशाखा महाउपासिका, धम्मिक उपासकहरू मरणपछि, देवलोकमा उत्पन्न भएको कुराहरू बौद्ध साहित्यमा उल्लेख छन् ।

घ) कटत्ताकम्म - होश नराखिकन जीवनमा कहिलेकाहीं गर्ने कर्मलाई 'कटत्ताकम्म' भनिन्छ। पागल व्यक्तिले लठीलाई जहाँतहिं फाल्ने भौं कटत्ताकर्मले मानिसलाई जहाँतहाँ नयाँ जन्म दिन्छ।

यसरी फल दिने ऋममा सर्वप्रथम गरुक कर्मले फल दिन्छ। यदि भारी कर्म गरेको छैन भने मरणासन्न अवस्थामा गरेको कर्मले फल दिन्छ, तर यी दुइवटै कर्म गरेको छैन भने फल दिने पालो आचिण्ण कर्मको हुन्छ। तर यी तीनवटै कर्म नगरेको अवस्थामा कहिलेकाहीं मात्र गरेको कटत्ताकम्मले फल दिन्छ। 99

मानिस मानिसमा समानता भएता पनि राम्रो फल नराम्रो फल भोग गर्ने सम्बन्धमा फरक हुने विषयमा भगवान् बुद्धले विभिन्न स्थानमा धेरै उपदेश दिनुभएको पाइन्छ। त्यसमध्ये सूत्रपिटकको मज्ञिकमनिकाय अन्तर्गत चूलकम्म विभड़ सुत्तमा ${ }^{२ ०}$ उल्लेख भएअनुसार भगवान बुद्ध श्रावस्तीको जेतवन विहारमा बसिरहनु भएको बेलामा शुभ नामक ब्राम्हणले वहाँलाई १४ वटा प्रश्न युगल रूपमा गरेका थिए।

"को नु खो, भो गोतम, हेतु को पच्चयो येन मनुस्सानंयेव सतं मनुस्सभूतानं दिस्सन्ति हीनप्पणीतता ? दिस्सन्ति हि, भो गोतम, मनुस्सा अप्पयुका, दिस्सन्ति दीघायुका; दिस्सन्ति बव्हाबाधा, दिस्सन्ति अप्पबाधा; दिस्सन्ति दुब्बण्णा, दिस्सन्ति वण्णवन्तो; दिस्सन्ति अप्पेसक्खा, दिस्सन्ति महेसक्खा; दिस्सन्ति अप्पभोगा, दिस्सन्ति महाभोगा; दिस्सन्ति नीचकुलीना, दिस्सन्ति उच्चकुलीना; दिस्सन्ति दुपञ्जा, दिस्सन्ति पन्जवन्तो। को नु खो भो गोतम, हेतु को पच्चयो येन मनुस्सानंयेव सतं मनुस्सभूतानं दिस्सन्ति हीनप्पणीतता ?

99 International Buddhist Meditation. Center 'Kamma condition' Part 4. Facebook. $5^{\text {th }}$ Dec. 2020. Access on $6^{\text {th }}$ Dec. 2020

https://m.facebook.com/story.php?story_fbid=3496248667126905\&id=100002254175913

२० विपश्यना विशोधन विन्यास, मज्भिमनिकायो -ततियो भागो, इगतपुरी : विपश्यना विशोधन विन्यास, १९९६, पृ. २ू०। 
"भो गौतम ! के हेतु के प्रत्यय हो जो कि मनुष्यहरूमा मनुष्य भइकन कुनै उच्च र कुनै नीच देखिन्छन् ? यहाँ अल्पायु पनि देखिन्छन्, दीर्घायु पनि देखिन्छन्; बहुरोगी पनि देखिन्छन्, अल्परोगी पनि देखिन्छन्; दुर्वर्ण पनि देखिन्छन, सुवर्ण पनि देखिन्छन्; अल्पशक्ति भएका पनि देखिन्छन्, महाभोगी पनि देखिन्छन्; नीचकुलीन पनि देखिन्छन्, उच्चकुलीन पनि देखिन्छन्; बुद्धिहीन पनि देखिन्छन्, बुद्धिमान पनि देखिन्छन् । भो गौतम ! यसप्रकार मनुष्यहरूमा मनुष्य भईकन उच्च, नीच हुनाको हेतु प्रत्यय के होला? "२१

भगवान् बुद्धले शुभ मानवकलाई जवाफ दिनुभयो

"कम्मसका माणव, सत्ता कम्मदायदा, कम्मयोनी कम्मवन्धू कम्मपटिसरणा । कम्म सत्ते विभाजति यदिदहीनप्पणीततायाति ।"२२

"हे मानव ! सत्वहरूको कर्म नै आ-आफ्नो सम्पत्ति हुन्छन्, कर्मकै अंशभागी बन्छन्, कर्म नै जन्मको कारण हुन्छ, कर्म नै आफ्ना नातेदार हुन्छन्, कर्म नै आफ्ना सच्चा शरण हुन्छ। कर्मले नै सत्वहरूलाई उच्चता र नीचतामा विभाजित गई। शुभ माणवकले उक्त संक्षिप्त जवाफलाई स्पष्ट रूपले नबुक्केकाले त्यसलाई विस्तृत रूपले व्याख्या गर्न प्रार्थना गरेपछि, भगवान् बुद्धले यसरी व्याख्या गर्नुभयो २३

\section{अल्पआयु र दीर्घायु हुनुको कारण}

कुनै स्त्री वा पुरुष जसले प्राणी प्रति निर्दयी भई हिंसा हत्या गर्दछ त्यस्तै कर्म गरी बस्छ। सो व्यक्ति मरणपछि दुर्गति नरकमा पतन हुन्छ। यदि दुर्गति नरकमा उत्पन्न नभई मनुष्य योनिमा जन्म लिंदा अल्पआयु हुन्छ। तर जसले हिंसा छाडी दण्डरहित शस्त्ररहित दयालु भई सबै प्राणी प्रति हितानुकम्पी भई त्यस्ता कर्म ग्रहण गरी बस्छ, त्यस्तो व्यक्ति मरण पछि सुगति स्वर्ग लोकमा उत्पन्न हुन्छ। यदि स्वर्ग सुगतिमा उत्पन्न नभई मनुष्य योनिमा जन्मने अवस्थामा दीर्घायु हुन्छ।

\section{रोगी र निरोगी हुनुको कारण}

कुनै स्त्री वा पुरुष जसले प्राणीहरूलाई हातले, लठीले, दण्डाले तथा शस्त्रले सास्ति गर्दछ, त्यस्तै कर्म ग्रहण गरी बस्छ। सो व्यक्ति मरणपछि दुर्गति नरकमा पतन हुन्छ। यदि दुर्गति नरकमा उत्पन्न नभई मनुष्य योनिमा जन्म लिंदा रोगी हुन्छ। तर जसले प्राणीहरूलाई आफू समान ठानी दया करुणा राखी सास्ति गर्दैन न त त्यस्ता कर्ममा मन लगाई त्यस्तै कर्म ग्रहण गरी बस्छ। सो व्यक्ति मरणपछि सुगति स्वर्ग लोकमा उत्पन्न हुन्छ। यदि स्वर्ग सुगतिमा उत्पन्न नभई मनुष्य हुन पुगदा निरोगी हुन्छ।

२१ दुण्डबहादुर, बज्राचार्य (अनु.), मजिकमनिकाय, ललितपुर: वीर-पूर्ण पुस्तक संग्रहालय, वि.सं २०४७, पृ. द२४।

२२ विन्यास, पूर्ववत् पादटिप्पणी नं. २०, पृ. २५०।

२३ बज्राचार्य (अनु.), पूर्ववत् पादटिप्पणी नं. २१, पृ. द२४। 


\section{रूप दुर्वर्ण र सुवर्ण हुनुको कारण}

कुनै स्त्री वा पुरुष जो कोधी, रिसाहा, अप्रसन्न हुन्छ, सो व्यक्ति मरणपछि दुर्गति नरकमा पतन हुन्छ। यदि दुर्गति नरकमा उत्पन्न नभई मनुष्य योनिमा जन्म लिंदा दुर्वर्ण कुरूप हुन्छ। तर जो ऋोध, रिस र अप्रसन्नता प्रकट नगरी सहनशील भएमा ऊ मरणपछि दिव्यलोकमा उत्पन्न हुन्छ। यदि दिव्यलोकमा उत्पन्न नभई मनुष्य योनिमा जन्म लिंदा रूप वर्ण राम्रो हुन्छ। यसरी अक्रोधी, सहनशील हुँदा सुन्दरताको मार्गमा पुच्याइदिन्छ।

\section{अल्पशक्ति र महाशक्ति सम्पन्न हुनुको कारण}

कुनै स्त्री वा पुरुष जसले अरुलाई प्राप्त हुने लाभ सत्कार, गौरव र पूजामा ईष्प्या गई। सो व्यक्ति मरणपछि दुर्गति नरकमा पतन हुन्छ। यदि दुर्गति नरकमा उत्पन्न नभई मनुष्यत्वमा पुगे पनि यश परिवार भाग्य विहीन भई अल्पशक्ति भएको हुन्छ। यसको विपरित जसको ईर्या चित्त छैन। अरुलाई प्राप्त सत्कार सम्मान मानमर्यादा देख्दा ईष््या चित्त राख्दैन भने ऊ मरणपछि सुगति स्वर्गलोकमा पुगिन्छ। यदि स्वर्ग सुगतिमा उत्पन्न नभई मनुष्य भएर जन्मिदा भाग्य यश परिवार बृद्धि भई महाशक्ति सम्पन्न हुन्छ, ।

\section{गरीब र धनी हुनुको कारण}

कुनै स्त्री वा पुरुष जसले दान दिन योग्य व्यक्तिहरूलाई भोजन चीजवस्तु इत्यादि दान गर्देन, अरुले दान दिंदा समेत रोक्ने गर्दछ। यस्ता व्यक्ति मरण भएमा दुर्गति नरकमा पुगिन्छ। केही भएर नरकमा पतन नभएता पनि फेरि मनुष्य जन्म लिंदा धनसम्पत्ति हीन भई गरीव हुन्छ। त्यस्तै कुनै स्त्री वा पुरुष जसले दक्षिणेय व्यक्तिहरूलाई अन्न पान चीजवस्तु इत्यादि दानप्रदान गर्दछ त्यस्ता व्यक्ति मरण भएमा सुगति स्वर्गलोकमा पुगिन्छ। केही गरेर दिव्यलोकमा नपुगेता पनि मनुष्य भएर जन्म लिंदा वैभव सम्पत्ति बृद्धि हुन्छ।

\section{नीच कुलीन र उच्च कुलीन हुनुको कारण}

कुनै स्त्री वा पुरुष जो अभिमानी हुन्छ। अभिवादन गर्नुपर्नेलाई अभिवादन, सत्कार र गौरव मान पूजा गर्नुपर्नेलाई सत्कार र गौरव मान पूजा गर्देन। ऊ मरणपछि दुर्गति नरकमा पतन हुन्छ। यदि सो मरणपछि दुर्गति नरकमा उत्पन्न नभई मनुष्यत्वमा आयो भने ऊ जहाँ जन्मन्छ, त्यहाँ नीच कुलीन हुन्छ। तर जो अभिमानी हुँदैन अभिवादन गर्नुपर्नेलाई अभिवादन, सत्कार र गौरव मान पूजा गर्नुपर्नेलाई सत्कार र गौरव मान पूजा गर्दछ,। ऊ मरणपछि सुगति, स्वर्गलोकमा उत्पन्न हुन्छ। यदि ऊ मरणपछि, सुगति, स्वर्गलोकमा उत्पन्न नभई मनुष्यत्वमा आयो भने ऊ जहाँ जन्मन्छ, त्यहाँ उच्च कुलीन हुन्छ।

\section{बुद्धिहीन र बुद्धिमान हुनुको कारण}

कुनै स्त्री वा पुरुष जसले श्रमण वा ब्राम्हणकहाँ गई कुशल र अकुशल, सेवन गर्नुपर्ने र सेवन गर्न नहुने, दीर्घकालसम्म अहित र दुखख तथा हित र सुख हुने धर्मबारे सोधपुछ गर्दैन। ऊ मरणपछि दुर्गति नरकमा पतन हुन्छ। यदि सो मरणपछि दुर्गति नरकमा उत्पन्न नभई मनुष्यत्वमा आयो भने ऊ जहाँ जन्मन्छ, त्यहाँ बुद्धिहीन 
(मूर्ख) हुन्छ। त्यस्तै जसले श्रमण वा ब्राम्हणकहाँ गई कुशल र अकुशल, सेवन गर्नुपर्ने र सेवन गर्न नहुने, दीर्घकालसम्म अहित र दु:ख तथा हित र सुख हुने धर्मबारे सोधपुछ गर्दछ। ऊ मरणपछि सुगति, स्वर्गलोकमा उत्पन्न हुन्छ। यदि ऊ मरणपछि, सुगति, स्वर्गलोकमा उत्पन्न नभई मनुष्यत्वमा आयो भने ऊ जहाँ जन्मन्छ, त्यहाँ बुद्धिमान (प्रज्ञावान) हुन्छ।

माथि उल्लेखित सूत्रको आधारमा बौद्ध जगतका प्रसिद्ध बर्माका विपश्यनाचार्य महासी सयादोद्वारा रचित स्मरणिका गाथालाई यहाँ उल्लेख गर्नु सान्दर्भिक देखिन्छ :

परहिंसाले हुन्छ, अल्पायु, दीर्घायु हुन्छ अहिंसाले । पर पीडाले धेरै रोगी, दयाले त निरोगी नै॥ द्वेष अगिने हुन्छ कुरूप, सहांदा हुन्छ सुरूप नै। ईष्या नगर्दा परिवार, प्रमुदितले यशस्वी हुन्छ नै॥ हुन्छ दरिद्र कपटले, त्यागले हुन्छ धनी पनि । अगौरवले नीच हुन्छ, उच्च कुलीन गौरवले ॥ अपरीक्षाले ज्ञान कमी, परीक्षाद्वारा ज्ञान बढी । नराम्रो गर्दा नराम्रोनै, राम्रो गर्दा राम्रोनै। गर्नुछ सुख दु:ख भोग, असल खराब सबै यहाँ $\|^{\text {२ }}$

\section{आफ्नो नाथ आफै}

परापूर्वकालदेखि आफ्नो जीवनलाई प्रभाव पार्ने र निर्देशित गर्ने अरु कोई भएको कुरालाई धैरैजसो धर्म सिद्धान्तमा मान्यता दिएको पाइन्छ। तर बुद्धले आफ्नो मालिक आफैं हो आफू बाहेक अरु कोही आफ्नो मालिक हुन सक्दैन भनेर आफ्नो प्रयासलाई सर्वोपरि महत्त्व दिई स्वावलम्बी हुने शिक्षा दिनुभएको छ। जुन धम्मपदमा ${ }^{\text {२ }}$ यसरी उल्लेख गरिएको छ :

अत्ता हि अत्तनो नाथो - को हि नाथो परो सिया ?

अत्तना'व सुदन्तेन - नाथं लभति दुल्लभं।

आफू नै आफ्नो मालिक हो, आफ्नो मालिक अरु को हुनसक्ला ? आफूलाई राम्रोसँग दमन गर्न सक्यो भने दुर्लभ स्वामित्व प्राप्ति हुन्छ।

२४ अमिता धाख्वा (सं), बुद्धभर्मका प्रारम्भिक ज्ञान,काठमाण्डौ: अन्तर्राष्ट्रिय बौद्ध भावना केन्द्र, वि.सं २०७३ पृ. ४७ २५ भिक्षु अमृतानन्द (अनु.),गाथा नं. १६०, पूर्ववत् पादटिप्पणी नं,२, पृ.७३ 
त्यस्तै आफूले गर्ने काम, बोल्ने बोली र गर्ने विचार कुशल वा अकुशल भएमा सोहीअनुसार शुद्ध वा अशुद्ध हुने कुरा धम्मपदमा र६ उल्लेख गरिएको छ -

अत्तना'व कतं पापं -अत्तना सक्षिलिस्सति ।

अत्तना अकतं पापं - अत्तना'व विसुज्कति ।

सुद्धी असुद्धी पच्चतं - नाज्जो अन्जं विसोधये ॥

आफुले गरेको पापले आफैलाई अपवित्र पार्दछ, आफूले गरेको पुण्यले आफैलाई शुद्ध पार्दछ, शुद्धि हुने र अशुद्धि हुने आफ्नै द्वारबाट हो, कसैले अरु कसैलाई शुद्ध पार्न सक्दैन ।

यस गाथामा चरित्रवान् व्यक्तिले आफ्नो शुद्धि र अशुद्धिको बाटो आफैं पहिल्याउन सक्दछ भन्ने उल्लेख भएको पाइन्छ। यसप्रकार बुद्धले आफ्नो प्रयासलाई सर्वोपरि महत्त्व दिई स्वावलम्बी हुने शिक्षा दिनुभएको छ।

\section{निष्कर्ष}

बुद्धशिक्षामा कुशल कर्म, अकुशल कर्म, कुशल बृद्धिका लागि गर्नुपर्ने क्रियाहरू राम्ररी विश्लेषण गरिएको पाइन्छ। कुशल कर्म उन्नतिको बाटो हो भने अकुशल कर्म अवन्नतिको बाटो हो । कुन बाटो रोज्ने व्यक्ति स्वयंमा भर पर्दछ। तर कुशल र अकुशल चिन्ने क्षमता भने आफूमा हुनु पर्दछ। त्यस अर्थमा बुद्धले आफ्नो मालिक आफैँ हो आफू बाहेक अरु कोही आफ्नो मालिक हुन सक्दैन भनेर मानिसको आफ्नो प्रयासलाई सर्वोपरि महत्त्व दिई धर्ममा स्वावलम्बी हुने शिक्षा दिनुभएको छ। कर्मको नियमअनुसार कुशल कर्मले राम्रो फल दिन्छ र अकुशल कर्मले नराम्रो फल दिन्छ। कर्म र कर्मफल बीच कारण र परिणामको सम्बन्ध रहेको हुन्छ। कुशल कर्म वा अकुशल कर्म कारण हो भने सुख, दु:ख तथा सुगति, दुर्गति प्राप्त हुनु फल वा परिणाम हो। कर्म र कर्मफलको अन्तरसम्बन्धको यर्थाथता र विविध प्रकारका कर्महरू सम्बन्धि तथ्यलाई आत्मसात गर्न नसक्दा मानिसले अकुशल कर्म गर्न पुग्छन, जुन कर्मले गर्दा आफूलाई मात्र नभई अरुलाई समेत हानी पुग्ने हुन्छ। कर्मको भागीदार आफू नै हो भन्ने कुराप्रति अनभिज्ञताको कारणले गर्दा आफ्नो चरित्र सुधारको बदलामा पाप मोचन विधि अपनाउने गर्दछ्। । तसर्थ कर्म र कर्मफल बारेमा सही दृष्टि भएमा अकुशल कर्मलाई त्यागी कुशल कर्म गर्ने तथा आफूभित्र असल गुणहरूको विकास गरी मनुष्य जीवनलाई सार्थक बनाउन सकिन्छ।

\section{सन्दर्भ सामग्री}

अनागारिका अगगजाणी(अनु. ), पपतित सूत्रया व्याख्या, काठमाण्डौ : अन्तर्राष्ट्रिय बौद्ध भावना केन्द्र, वि.सं २०६७। अनागारिका अगगजाणी, पालि शिक्षा र संक्षिप्त व्याकरण, काठमाण्डौ : दिलरत्न शाक्य र विद्या शाक्य, वि.सं २०६७।

अनागारिका अगगजाणी, सद्धर्म पुष्पमाला, ललितपुर: अष्ट रत्न धाख्वा, रत्नदेवी धाख्वा परिवार, वि.सं २०७० ।

२६ उही गाथा नं १६४ पृ.७५ 
धाख्वा अमिता र अरुहरू (सं), परियत्ति शिक्ष तह-२, काठमाण्डौ : अखिल नेपाल भिक्षु महासंघ, वि.सं २०७७। धाख्वा अमिता (सं), बुद्धधर्मका प्रारम्भिक ज्ञान, काठमाण्डौ : अन्तर्राष्ट्रिय बौद्ध भावना केन्द्र, वि.स २०७३ । बज्राचार्य, दुण्डबहादुर (अनु. ), मजिकमनिकाय, ललितपुर : वीर-पूर्ण पुस्तक संग्रहालय, वि.सं २०४७। बज्राचार्य, दुण्डबहादुर, (अनु.), संयुक्तनिकाय, ललितपुर : वीर-पूर्ण पुस्तक संग्रहालय, वि.सं २०४५ । भद्दन्त सम्यकसम्बोधि प्राणपुत्र, सम्यक शिक्षा, बेनी : म्यागदी बौद्ध संघ, वि.सं. २०६३। भिक्षु अमृतानन्द (अनु.), धम्मपद, काठमाण्डौ : आनन्दकुटी विहार संस्था, वि.सं २०७०। भिक्षु बोधिसेन महास्थविर (अनु.), अडुत्तर निकाय (छक्क निपात), ललितपुर : अनागारिका वीर्यपारमिता, २०६७। भिक्षु ज्ञानपूर्णिक (अनु.), कर्म र मनुष्य, ललितपुर : सन्ति सुखावास, वि.सं २०४४। विपश्यना विशोधन विन्यास, अहुत्तर निकायो (दुतियो भागो), इगतपुरी : विपश्यना विशोधन विन्यास, १९९५ । विपश्यना विशोधन विन्यास, अभिधम्मत्थसड़हो अभिधम्मत्थविभाविनीटीका, इगतपुरी: विपश्यना विशोधन, १९९६।

विपश्यना विशोधन विन्यास, मज्किमनिकायो (ततियो भागो), इगतपुरी : विपश्यना विशोधन विन्यास, १९९६। International Buddhist Meditation. Center 'Kamma condition'. Part 4. Facebook. $5^{\text {th }}$ Dec. 2020. Access on $6^{\text {th }}$ Dec. 2020

https://m.facebook.com/story.php?story_fbid $=3496248667126905 \& i d=100002254175913$ 